\title{
Review
}

\section{Review of major sweetpotato pests in Japan, with information on resistance breeding programs}

\author{
Yoshihiro Okada*1), Akira Kobayashi' ${ }^{2)}$, Hiroaki Tabuchi ${ }^{2)}$ and Toshikazu Kuranouchi ${ }^{3)}$ \\ 1) Division of Agro-Environment Research, Kyushu Okinawa Agricultural Research Center, NARO, Itoman, Okinawa 901-0336, Japan \\ 2) Division of Upland Farming Research, Kyushu Okinawa Agricultural Research Center, NARO, Miyakonojyo, Miyazaki 885-0091, \\ Japan \\ 3) Division of Field Crop Research, Institute of Crop Science, NARO, Tsukuba, Ibaraki 305-8518, Japan
}

\begin{abstract}
Sweetpotato (Ipomoeae batatas (L.) Lam.) is an important food crop affected by several pests throughout the world, especially in tropical, subtropical, and temperate regions. Although Japan is relatively free from many serious sweetpotato pests, some pests, especially soil-borne pathogens, viruses, and insects such as plantparasitic nematodes and weevils, cause severe damage in Japan. In this review, we describe the current status and management options for sweetpotato pests and diseases in Japan and review research related to sweetpotato breeding that can promote resistance to these problems. Furthermore, we describe methods to evaluate resistance to pests and disease used in sweetpotato breeding at the National Agriculture and Food Research Organization (NARO).
\end{abstract}

Key Words: sweetpotato, soil rot disease, viruses, nematodes, insect pests, resistance breeding, pests control.

\section{Introduction}

The sweetpotato, Ipomoea batatas (L.) Lam., is currently ranked as the seventh most important crop in the world with a total production of 103 million tons in 2013 (FAOSTAT 2015). It is produced largely in Asia (accounting for up to $76.1 \%$ of world production in 2013), followed by the African continent (19.5\%) (FAOSTAT 2015). The top five sweetpotato-producing nations in 2014 were China, Nigeria, Uganda, Indonesia, and the United Republic of Tanzania (FAOSTAT 2015). After the potato (Solanum tuberosum L.) and cassava (Manihot esculenta Crantz), sweetpotato is the third most important root crop in the world (FAO 1998). Sweetpotato is an important crop in tropical, subtropical, and temperate areas, and it is an efficient producer of starch.

The local crop production system influences exposure of sweetpotatoes to disease and insect pests. Sweetpotato is an indeterminate plant that is usually grown as an annual crop. In tropical regions, it can be grown all year long and is typically propagated from vine cuttings taken from other production fields. In temperate and subtropical regions, where winters are too harsh for year-long production, roots are

Communicated by Kenji Katayama

Received August 30, 2016. Accepted October 31, 2016.

First Published Online in J-STAGE on February 17, 2017.

*Corresponding author (e-mail: yoc1973@affrc.go.jp) stored over the winter and used to produce slips to transplant during the following season. It is not always clear how local environments, differences in susceptibility of local cultivars, or differences in occurrence of pathogens and insects contribute to location-based differences in the occurrence of pests. Several diseases and pests are transmitted from one season to the next by their ability to infect storage roots and are more problematic in temperate production systems. Some diseases and pests mainly occur in plant beds used in temperate production systems to produce slips from storage roots.

Although sweetpotato is susceptible to over 40 diseases, 20 viruses, and 40 species of insect pests worldwide (Clark et al. 2009, Loebenstein et al. 2009, Sorensen 2009), it is relatively free from several serious pests in Japan. However, black rot plant bed disease (Ceratocystis fimbriata), soil rot (Streptomyces ipomoeae), stem rot (Fusarium oxysporum $\mathrm{f}$. sp. batatas), and some viral diseases have been reported in Japan. Southern root-knot nematode (Meloidogyne incognita), three genera of Lepidoptera (Aedia, Helcystogramma, Spodoptera), beetles (Anomala spp.), and two genera of weevils [Cylas formicarius (Fabricius) and Euscepes postfasciatus (Fairmaure)] have also been reported in Japan. Pests occurring in plant beds as well as soil-borne pests/ pathogens, viruses, and plant-parasitic nematodes are the major pests, and they cause considerable damage to sweetpotatoes in temperate regions of Japan (Honsyu, Kyusyu, and Shikoku). In particular, two genera of weevils cause 

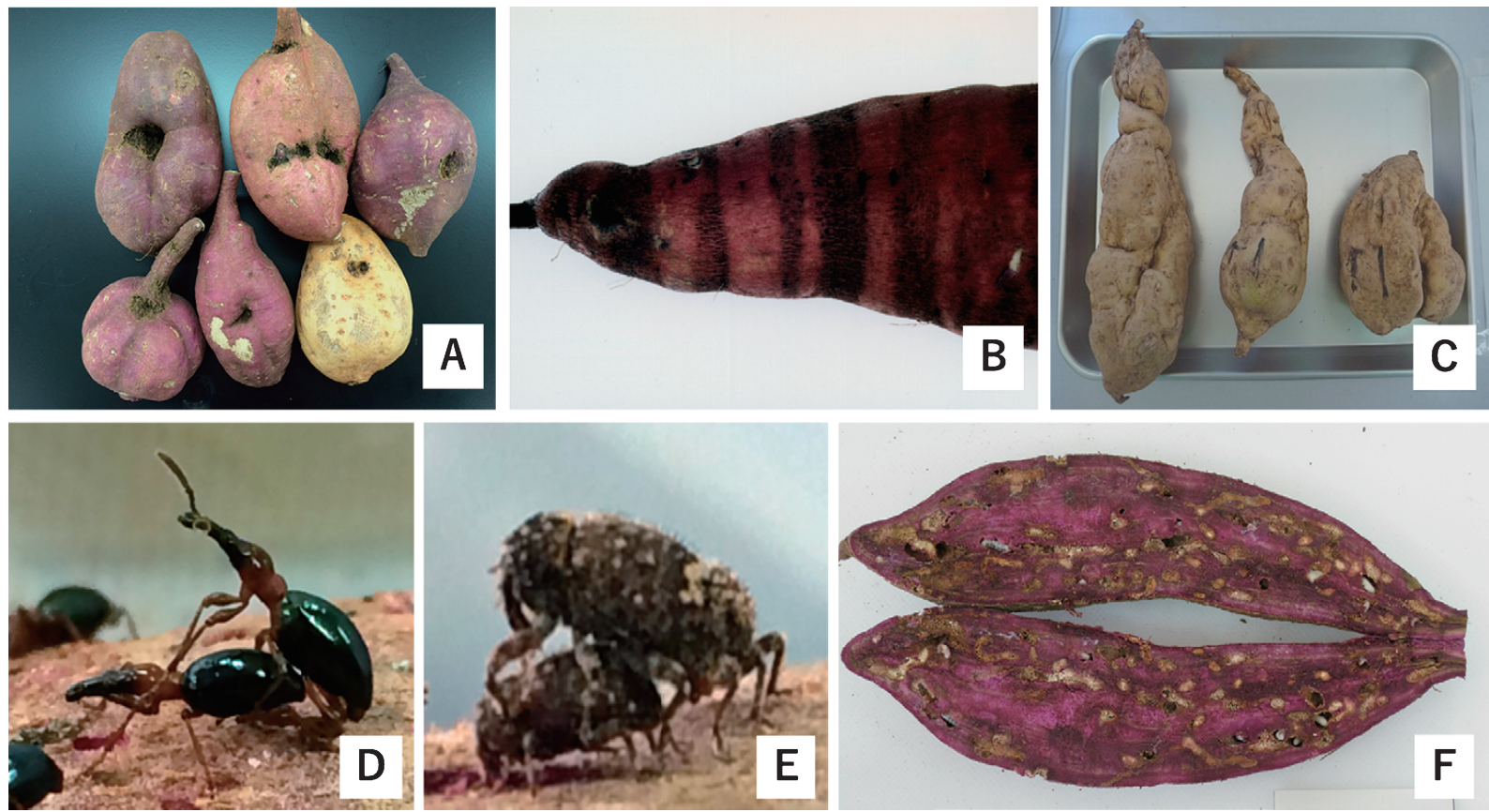

Fig. 1. Major sweetpotato disease and pests. A: Streptomyces soil rot caused by Streptomyces ipomoeae. B: Russet cruck disease symptoms caused by sweet potato feathery mottle virus server strain, called 'Obijyo-sohi' in Japan. C: Storage roots of susceptible sweetpotato cultivar 'Koganesengan' infested by root-knot nematode (Meloidogyne spp.). (Courtesy M. Suzuki) D: Adults of sweetpotato weevil (Cylas formicarius (Fabricius)). E: Adults of West Indian sweetpotato weevil (Euscepes postfasciatus (Fairmaure)). F: Invaded storage root by weevils.

serious damage to sweetpotato production in the subtropical to tropical southwestern island region of Japan, including the Okinawa prefecture.

This review focuses on problems facing sweetpotato cultivation in Japan, including soil rot (Streptomyces ipomoeae), viral disease (caused by Sweet potato feathery mottle virus), southern root-knot nematode (Meloidogyne incognita), and two genera of weevils [Cylas formicarius (Fabricius) and Euscepes postfasciatus (Fairmaure)] (Fig. 1). Resistant cultivars are effective for management of these pests: therefore, we describe a recent study on breeding of resistant cultivars and genetic analyses of resistant sweetpotato genes. Furthermore, we evaluated the resistance to stem rot, soil rot, black rot, southern root-knot nematode and coffee root-lesion nematode in our breeding program in National Agriculture and Food Research Organization (NARO), and report an outline of information and evaluation methods for the breeding program.

\section{Soil rot}

Streptomyces soil rot or pox is a destructive disease of sweetpotato that is caused by the soil-borne actinomycetes Streptomyces ipomoeae (Person and Martin) Waksman and Henrici. Soil rot in sweetpotatoes was first described by Halsted in 1890. Soil rot was initially thought to have a fungal etiology until 1929, when the causal agent was identified as an actinomycete bacteria, Actinomyces pox (Loria et al. 1997). The pathogen was renamed Actinomyces ipomoeae by Person and Martin in 1940, then S. ipomoeae (Person and Martin) Waksman and Henrici, and finally S. ipomoeae by Waksman in 1957 (Locci 1994). Occurrence of soil rot in Japan was recognized around 1946 in Nagasaki (Suzui 1987), and the causal pathogen was identified by Suzui et al. (1986).

After transplanting slips to the field infested with the soil-rot pathogen, the pathogen infects fibrous roots. Infected fibrous roots become necrotic and decay. Small, elongated, black sunken cankers may develop on the slips below ground, stunting the vine, causing bronzing and chlorosis in foliage and eventual plant death and decreasing crop yield (Clark and Moyer 1988a, Locci 1994, Loria et al. 1997). In addition, the disease decreases crop quality by causing necrotic lesions on storage roots, which make the product unmarketable. Symptoms on the root include scab lesions, which are circular to somewhat irregular in outline, and are usually $<5$-mm deep and $3 \mathrm{~cm}$ in diameter.

Several environmental factors affect the incidence of soil rot. Soil $\mathrm{pH}$ appears to have the largest influence. Soil rot does not develop in soil with $\mathrm{pH}<5.2$, and disease severity increases progressively as the $\mathrm{pH}$ increases to $>5.2$ (Clark and Moyer 1988a). Similarly, Ogawa et al. (1979) reported minimal disease development in soil at $\mathrm{pH} \leq 4.5$, and more severe disease development above at $\mathrm{pH} \geq 6.0$ (Kudo 1985). Soil temperature also influences the disease. The disease develops in the range of $25^{\circ} \mathrm{C}-40^{\circ} \mathrm{C}$, with an optimum temperature of approximately $35^{\circ} \mathrm{C}$, and no development in soil $<20^{\circ} \mathrm{C}$ (Kudo 1985). Poole (1925) showed a negative 
correlation between the soil moisture levels and disease. The development of soil rot is favored by relatively dry soil (Clark and Moyer 1988a). High soil water content stimulates a more rapid development of roots and allows a diseased plant with a deficient root system to absorb the water and essential salts more easily from the soil (Locci 1994).

The most effective management strategies are the use of resistant cultivars. Several resistant cultivars have been released in the United States to provide soil-rot control (Loria et al. 1997). However, highly resistant cultivars were not developed in Japan and only a moderately resistant cultivar 'Beniazuma' has been released (Shiga et al. 1985). Evaluating sweetpotato genotypes for resistance to soil rot is important to produce resistant cultivars and generally takes place on naturally infested fields. However, field tests have continually changing environmental conditions and relatively large experimental error. Furthermore, securing the infested field is labor-intensive and time-intensive. Therefore, several methods to evaluate sweetpotato genotypes for resistance to soil rot have been developed using a laboratory or greenhouse. Moyer et al. (1984) evaluated stem cutting and root slices for resistance to soil rot, after 10 weeks of growth in infested sand under greenhouse condition and after incubation on infested sand, respectively, for 7-14 days at $30^{\circ} \mathrm{C}$. Ino et al. (1985) and Takano et al. (2006) evaluated sweetpotato slips for resistance to soil rot after growth in cups with infested soil incubated in a thermobath to precisely control soil temperature. Iuchi et al. (2005) developed methods to evaluate resistance to soil rot inoculating by small vine cuttings and storage root slices. These methods can help screen for resistance, especially in breeding programs where field test cannot be performed. The first soil rot resistant cultivar 'Jasper' was released in the United States in 1975 (Clark et al. 1992). Subsequently, 'Travis', 'Eureka', and 'Beauregard' have been released. These cultivars have significant levels of resistance. In Japan, the moderately resistant cultivar 'Beniazuma' exhibited the strongest resistance against soil rot among the existing cultivars (Ino et al. 1985, Iuchi et al. 2005, Kuranouchi et al. 2014, Takano et al. 2006). In addition, ' $90 \mathrm{IDN}-47$ ' was selected as a resistant line from genetic resources of sweetpotato, and has been used for breeding material (Kuranouchi et al. 2014).

\section{Virus diseases}

Viral diseases among sweetpotatoes are widespread and can cause serious damage to the plants. Sweetpotatoes are vegetables propagated from vines, root slips, or storage roots, and farmers often take vines for propagation from their own fields. Thus, if viruses are present in the field 1 year, they will be transmitted with the propagation material to the newly planted field, potentially impacting yield. The sweetpotato is prone to infection by sweet potato feathery mottle virus (SPFMV). Numerous viruses infect sweetpotatoes worldwide (Clark and Moyer 1988b, Cohen et al. 1997, Moyer et al. 1989, Moyer and Larsen 1991, Moyer and
Salazar 1989, Rossel 1981). These include sweet potato chlorotic stunt virus (Cohen et al. 1992, Hoyer et al. 1996a, 1996b), sweet potato leaf curl virus (SPLCV) (Chung et al. 1985, Green et al. 1992, Liang et al. 1990, Osaki and Inouye 1991) and ipomoea crinkle leaf curl virus. However, they have not been comprehensively described. Five of these viruses have been reported in Japan: SPFMV (Usugi et al. 1994), SPLCV (Usugi et al. 1991), sweet potato latent virus (Usugi et al. 1991), sweet potato symptomless virus (Usugi et al. 1991) and sweet potato virus G (Sakai et al. 1997).

SPFMV has serious impacts on sweetpotato production and quality, and a severe strain causes 'obijo-sohi' disease in Japan. The russet crack strain (RC) has been isolated in the United States (Cali and Moyer 1981), and the severe strain (S) has been isolated in Japan (Usugi et al. 1994). In addition, the reported strains in Japan included the ordinary (O) strain (Mori et al. 1994), Tokushima (T) strain (Sakai et al. 1995), and protective mild strain (JC) of SPFMV (Yamasaki et al. 2000). SPFMV is transmitted by aphids (Myzus persicae) and the infected tuberous roots are used for vegetative propagation. As a result, the disease spreads rapidly in the field and does not respond to pesticides. Because the virus is not transmitted to the seed, clean seed stocks can be produced. However, because of the possibility of segregating agricultural phenotypes, propagation by the seeds is neither economical nor common. Shoot-apex culture has been used to overcome virus damage to sweetpotatoes in Japan (Nagata 1984). This method supplies virusfree young sweetpotatoes, but it is costly, and sweetpotatoes can still become infected after cultivation. Breeding of SPFMV-resistant plants was initiated by CIP (Mihovilovich et al. 2000). Prior efforts of virus resistance breeding focused on control of SPFMV given its universal distribution. However, many sweetpotato cultivars are naturally resistant to SPFMV, either showing no symptoms or recovering from mild initial symptoms, and demonstrating very low-virus titers (Kokkinos and Clark 2006). Several clones that were resistant to SPFMV in CIPs tests were susceptible when exposed to Israeli and Ugandan isolates (Karyeija et al. 1998). Strain diversity appears to require that breeding and selection take place in various locations. On the other hand, a substantial number of African sweetpotato landraces have resistance to this virus (Carey et al. 1997). Another approach was to develop transgenic sweetpotatoes with coatprotein mediated resistance to SPFMV (Okada et al. 2001, 2002, 2008a, 2008b). This type of resistance has been successful against a number of viruses in several crop species (Latham and Wilson 2008). However, resistance that works under controlled experimental conditions may not necessarily work in the field.

\section{Southern root-knot nematode}

The southern root-knot nematode, Meloidogyne incognita, is one of the most destructive pests. It is generally found in 
most areas where sweetpotatoes are grown worldwide, and attacks not only sweetpotato but also thousands of agronomic plants (Overstreet 2009). This nematode infects a wide range of plants, interfering with crop rotation and making it difficult to expel. Especially in Japan, this species is a primary sweetpotato pest. In the central and southern region of Kyushu including Kagoshima, Miyazaki and Kumamoto prefectures, major production area for sweetpotatoes, $96 \%$ of Meloidogyne spp. found in most sweetpotato fields were identified as M. incognita (Iwahori et al. 2000). This species was also detected in the northern region of Kanto including Ibaraki and Chiba prefectures, the second major production area for sweetpotato (Iwahori et al. 2015, Yoshida 1965). Sano and Iwahori (2005) indicated that nine races, SP1 to SP9, were identified from 129 populations collected from Kyushu and Okinawa, Japan, based on different responses to five sweetpotato cultivars. A primary race differed by region: SP1 was predominant in central and northern region in Kyushu, SP2 in southern region in Kyushu, and SP4 and SP6 in Okinawa. SP4 and SP6 were also identified in Ibaraki and Chiba (Momota et al. 2012).

Clark and Mayer (1988c), Overstreet (2009) and other researchers described symptoms and agronomic damage caused by this species. Characteristic symptoms include round to spindle-shaped swelling (galls), which have often egg masses on its surface, on the fibrous sweetpotato roots. Cracks, holes, constrictions, or blisters decrease storage root quality. Yield loss of storage roots also occurred, resulting lower yield of marketable production (Nielsen and Sasser 1959). Agu (2004) reported that nematode infection reduced shoot growth, shoot-to-storage root ratio and days to maturity as well as marketable yield. Such reduction in growth of top and roots is considered to result from reductions in the whole root system caused by inhibiting formation and growth of lateral roots as well as a reduction of feeder roots (Yamashita 2003). Loss in global yield by various nematodes including $M$. incognita was about $10.2 \%$, and monetary loss was about 2.6 billion US dollars (Sasser and Freckman 1987).

Nematicides can lessen quality and yield damage from nematodes (Johnson and Cairns 1971, Nielsen and Sasser 1959, Suzuki et al. 2012). Treatment of a parasitic bacterium Pasteuria penetrans and preceding cropping of nematode resisting oat 'Tachiibuki' reduced density of nematodes (Tateishi et al. 2007, 2008). We can also use resistant cultivars. Southern root-knot nematodes can infect the roots of resistant sweetpotato (Komiyama et al. 2006, Kondo 1972), but this infection tends to induce necrosis that seems to be related to resistance of sweetpotato (Gentile et al. 1962, Giamalva et al. 1963, Komiyama et al. 2006). Sasser and Freckman (1987) indicated 31\% of nematologists could access nematode-tolerant or nematode-resistant seeds or rootstocks based on worldwide surveys. Recently released cultivars resistant or tolerant to this species include 'Evangelin', 'Covington', 'Beniharuka', 'Konamizuki', 'Hoshikogane', and 'Aikomachi' (Kai et al. 2010, Katayama et al. 2012,
Kuranouchi et al. 2015, La Bonte et al. 2008, Ohara-Takada et al. 2016, Yencho et al. 2008). Resistant cultivars are effective for management of nematodes: however, Nishizawa (1974) found a pathotype of M. incognita that could break through resistant sweetpotatoes, and Tateishi (2003) described increasing density of nematodes after alternating resistant cultivar with a susceptible cultivar. These results may be because of invasion by new races. Suzuki et al. (2012) indicated that southern root-knot nematodes decreased yield even in resistant sweetpotato cultivars 'J-red' and 'Kyushu No. 139' under high nematode density conditions. A combination of nematicides, resistant cultivars, crop rotation, and other methods of cultural control is needed for long-term and effective control of nematodes.

Although the sweetpotato has a complex genetic nature (an outcrossing hexaploid species with many chromosomes, $2 n=6 x=90$ ), several genetic analyses have been reported, including the development of DNA markers associated with southern root-knot nematode-resistant genes. The observed distribution models of $F_{1}$ populations (bimodal, binominal, or biased), speculated inheritance models of resistant genes (simplex or duplex), number of DNA markers, and whether resistance was controlled qualitatively or quantitatively varied with each analysis (Table 1). These results suggest that sweetpotatoes have a few dominant genes with a strong resistance effect and several genes with weak resistance effects. In tomatoes, resistance to root-knot nematode was controlled by the single dominant gene Mi (Gilbert 1958), which was isolated by Milligan et al. (1998). Isolation of nematode-resistant genes in sweetpotatoes can promote our understanding of resistance mechanisms.

\section{Weevils}

Two genera of weevils, Cylas and Euscepes, are the most serious weevil pests affecting sweetpotatoes (Ames et al. 1997, Jansson and Raman 1991, Smith et al. 2013). The weevil Cylas formicarius (Fabricius) and the West Indian weevil Euscepes postfasciatus (Fairmaure) are major sweetpotato pests. These two species have caused enormous economic damage to farmers cultivating the sweetpotato in countries in Central and South America, the South Pacific Islands (Sherman and Tamashiro 1954). In Japan, weevils damage sweetpotatoes in the Nansei Islands, including the Okinawa prefecture, where weevils are an obstacle to agricultural advancement in the region. The Plant Protection Law prohibits shipping sweetpotatoes from infested to uninfested regions in Japan. In the worst cases, weevils can completely eliminate storage root production (Talekar 1988). Insecticides are the primary method of control, although they are not always effective because of the weevil's cryptic behavior (Jansson 1992). A weevil eating a storage root may cause relatively little physical damage to the storage root, mostly creating cosmetic problems on the surface or in the flesh. However, infestation by one weevil induces the production of secondary metabolites, ipomeamarones, 
Table 1. Genetic analysis and DNA markers associated with southern root-knot nematode

\begin{tabular}{|c|c|c|c|c|c|c|c|c|c|}
\hline $\begin{array}{l}\text { Type of } \mathrm{F}_{1} \\
\text { progenies }\end{array}$ & $\begin{array}{c}\text { No. of } \\
\text { progenies }\end{array}$ & Parents $^{a}$ & $\begin{array}{l}\text { Distribution } \\
\text { model }\end{array}$ & $\begin{array}{c}\text { Segregation } \\
\text { ratio (resistance: } \\
\text { susceptible) }\end{array}$ & $\begin{array}{l}\text { Inheritance } \\
\text { model }^{b}\end{array}$ & $\begin{array}{c}\text { Resistant } \\
\text { control }\end{array}$ & $\begin{array}{l}\text { Type of } \\
\text { marker }\end{array}$ & $\begin{array}{l}\text { No. of } \\
\text { markers }\end{array}$ & Reference \\
\hline full-sibs & 71 & Regal (r) × Vardaman (s) & $\begin{array}{c}\text { bimodal } \\
(\text { logaritm) }\end{array}$ & $4: 1$ & duplex & qualitative & RAPD & 1 & Ukoskit et al. (1997) \\
\hline half-sibs & 48 & $\begin{array}{l}\text { Beauregard (s), Excel, L94-96 (r), } \\
\text { L89-110, L86-33, L96-117 } \\
\text { (Open polination) }\end{array}$ & $\begin{array}{c}\text { bimodal } \\
\text { (logaritm) }\end{array}$ & - & - & qualitative & AFLP & 5 & Mcharo et al. (2005) \\
\hline full-sibs & 55 & $\begin{array}{l}\text { Beauregard }(\mathrm{s}) \times \text { Wagabolige } \\
\text { Kyukei No. } 63 \times \text { Jonathan W218 } \\
\text { Jonathan W154 } \times \text { Wagabolige } \\
\text { CN1732- } 4 \times \text { Jonathan W218 } \\
\text { Tanzania } \times \text { Wagabolige } \\
\text { Tanzania }(\text { Open polination })\end{array}$ & $\begin{array}{l}\text { binominal } \\
\text { (logaritm) }\end{array}$ & - & - & quantitative & AFLP & 4 & Mcharo et al. (2005) \\
\hline full-sibs & 240 & Tanzania $(\mathrm{r}) \times$ Beauregard $(\mathrm{s})$ & biased & - & - & quantitative & AFLP & 9 & $\begin{array}{l}\text { Cervantes-Flores et al. } \\
\text { (2008) }\end{array}$ \\
\hline full-sibs & 86 & Hi-Starch $(\mathrm{r}) \times$ Koganesengan $(\mathrm{s})$ & biased & $1: 1$ & simplex & qualitative & SCAR & 2 & Nakayama et al. (2012) \\
\hline
\end{tabular}

${ }^{a}(\mathrm{r})$ : resistant, (s): susceptible. No symbol: no coment about resitance or susceptibility was discribed by authors.

${ }^{b}$ duplex: RRrrr in resistant parent and rrrrr in susceptible parent, simplex: Rrrrr in resistant parent and rrrrrr in susceptible parent.

which decrease the storage root value. The ipomeamarones belong to the sesquiterpene class, cause the storage root to taste bitter and astringent, and are toxic to animals (Uritani 2001). Therefore, storage roots damaged by weevils cannot be used for any purpose (de Menezes 2002, Jansson and Raman 1991).

There are two possible solutions: breeding an ipomeamarone-free cultivar or breeding a weevil-resistant cultivar. There is currently no hope of achieving the first option, but the second option is practical. Natural resistance to pests is present in almost all crops (Collins et al. 1990), although resistance to E. postfasciatus is less documented than resistance to Cylas spp. (Raman and Alleyne 1991), potentially because of the wider distribution of Cylas spp. (Wolfe 1991). Polyphenol substances found in some sweetpotato cultivars play an important role in resistance to Cylas weevils (Muyinza et al. 2012). These substances may also provide resistance to E. postfasciatus. In areas where both species of weevils occur sympatrically, the damage to sweetpotatoes should be evaluated separately for E. postfasciatus and Cylas formicarius (F.) or its other congeneric species. On the Nansei Islands, located in southern Japan, sweetpotatoes are seriously damaged by both species, and the weevil population is highest from May to October (Yasuda 1993, 1997). Their damage to the sweetpotato stems varies with the time of planting of the crop, becoming apparent 30-60 days after planting from April to September, but 90-120 days after planting during the cooler months. The time lag between planting and the first appearance of damage relates to the invasion of weevils and their population increase in the field (Yasuda 1997). The resistance of sweetpotato to weevils should be examined in terms of the adult's preference for ovipositing on specific cultivars, which may relate to the suitability of the storage roots for larval growth (Wiklund 1975). Even if adults prefer a given cultivar for food and oviposition, the pest cannot increase rapidly unless the quality of the storage root also provides for larval development. Sweetpotato resistance to weevils has been reported in the laboratory and field (e.g., Blank et al. 2001, Bottega et al. 2010, França and Ritschel 2002, Okada et al. 2014, 2015, Silva and Ritschel 2001, Wanderley et al. 2004). However, few studies have considered the preference of weevil adults for certain cultivars and the suitability of the preferred cultivars for the juvenile development.

Early research focused on transformation with proteins that decrease the digestibility of sweetpotatoes for insects. Newell et al. (1995) transformed sweetpotato with a cowpea (Vigna unguiculata) trypsin inhibitor and the mannose binding snowdrop lectin. Cipriani et al. $(1999,2001)$ transformed sweetpotatoes with a soybean (Glycine max) Kunitztype trypsin inhibitor and a rice (Oryza sativa) cysteine protease inhibitor. Non-choice feeding tests with the E. postfasciatus in a screenhouse bioassay (Zhang et al. 2002) revealed a moderate increase in weevil resistance in two transgenic events (Newell et al. 1995). More recently, toxins from Bacillus thuringiensis (Bt) were tested against Cylas spp. Diet incorporation tests measured toxicity of eight Bt proteins, chosen based on prior evidence of toxicity (Maingi et al. 2002) or anti-Coleopteran activity. All Bt proteins tested were toxic to both species at $<1 \mathrm{ppm}$, with two proteins consistently more toxic than the others (Moar et al. 2007).

Evaluation of resistance to diseases and nematodes in sweetpotato breeding

Stem rot, soil rot, black rot, southern root-knot nematode and coffee root-lesion nematode are especially important for their impact on sweetpotatoes. We evaluated the resistance to these diseases and pests in our breeding program in NARO, and we have outlined our evaluation recommendations below. 
Stem rot (Fusarium oxysporum f. sp. batatas)

Stem rot of sweetpotato is caused by the soil-borne pathogenic fungi, Fusarium oxysporum f. sp. Batatas. The disease causes fibrous root rot and decreasing crop yield. Sterilization of vines before transplanting and soil sterilization are effective for prevention of the disease. The difference of resistance to this disease is obvious among cultivars.

Bud-cell suspension cultures of $F$. oxysporum provide a source for inoculation (Ogawa et al. 1979). Optimal density of the bud cell is $1 \times 10^{7}$ spores $/ \mathrm{ml}$. Cut sprouts of sweetpotato cultivars and lines are dipped into the pathogen suspension just before planting in early June. To raise temperature, the rows in the experimental field should be covered with transparent mulch film. The investigation continues through late July when 'Benikomachi' is highly diseased. The invasion of $F$. oxysporum, i.e., the internal browning of vines, is checked to indicate parasitism by stem rot disease using an index ranging from 1 (healthy) to 6 (dead). The resistance of experimental cultivars and lines of sweetpotato to stem rot is determined by referring the index of 'Benikomachi' (susceptible), 'Beniazuma' (intermediate) and 'Tamayutaka' (slightly resistant).

\section{Soil rot (Streptomyces ipomoeae)}

The resistance of sweetpotato cultivars and lines to soil rot should be evaluated in an infested field. Lime fertilizer increases soil $\mathrm{pH}$ and promotes infection. To raise the ground temperature, the rows in the experimental field should be covered with transparent mulch film. The cut sprouts of sweetpotato cultivars and lines are planted on early June. The investigation is carried out in early August when 'Kokei No. 14' is highly diseased. Roots are harvested and symptoms are observed. The internal browning of vines, lesions by S. ipomoeae, and delayed growth indicate parasitism using an index ranging from 1 (healthy) to 6 (dead). The resistance of experimental cultivars and lines of sweetpotato to soil rot is determined by referring the index of 'Kokei No. 14' (susceptible), 'Benikomachi' (slightly susceptible), 'Beniazuma' (slightly resistant), and '90 IDN-47' (resistant) (Kuranouchi et al. 2014).

\section{Black rot (Ceratocystis fimbriata)}

Black rot of sweetpotato is caused by the soil-borne pathogenic fungi, Ceratocystis fimbriata. The disease causes necrotic lesions on storage roots, and decreases quality. Sterilization of storage roots before burying in nursery bed, soil sterilization and crop rotation are effective for prevention of the disease. The difference of resistance to this disease is obvious among cultivars.

The slant medium is used to cultivate Ceratocystis fimbriata mycelium. Spores are collected and suspended in distilled water. The cut end of sweetpotato sprouts are dipped into the pathogen suspension. Inoculated cut sprouts are incubated at $30^{\circ} \mathrm{C}$ with high humidity for $4-5$ days. Grayish mycelia are formed at their cut ends after incubation. The cut sprouts are planted in the experimental field in mid-July, and the investigation is carried out through mid-September. The internal browning of vines and lesions on the surface of tuberous roots by $C$. fimbriata are checked to indicate parasitism by black rot using an index ranging from 1 (healthy) to 5 (severe). The resistance of experimental cultivars and lines of sweetpotato to black rot is determined using the index of 'Koganesengan' (susceptible), 'Harukogane' (slightly susceptible), 'Beniazuma' (intermediate) and 'Tamayutaka' (resistant). Rapid methods for evaluating the resistance of sweetpotato cultivars and lines to black rot have been reported (Mori et al. 1961).

\section{Southern root-knot nematode (Meloidogyne} incognita)

The resistance of sweetpotato cultivars and lines to southern root-knot nematode has been evaluated in infested fields. 'Kanto No. 14', a susceptible line, was cultivated to increase nematodes the previous year. The cut sprouts of sweetpotato cultivars and lines were planted in an experimental field mid-May, with investigation mid-July (Kuranouchi et al. 2012). The fibrous root systems are individually harvested and carefully washed. They are dyed with $0.05 \%$ Phloxine B water solution for 30 minutes and are checked for egg-mass formation. Parasitism of $M$. incognita is indicated with an index ranging from 1 (healthy) to 5 (severe). The resistance of experimental cultivars and lines of sweetpotato to southern root-knot nematodes is determined by referring the index of 'Kanto No. 14' (susceptible), 'Kokei No. 14' (slightly susceptible), 'Beniazuma' (intermediate) and 'J Red' (resistant). Differences in parasitism among the races of $M$. incognita have been studied (Sano and Iwahori 2005). Breeding a multi-raceresistant line is an important goal. Seedling selection is effective on the rapid breeding of resistant lines (Kuranouchi et al. 2013).

\section{Coffee root-lesion nematode (Pratylenchus coffeae)}

Coffee root-lesion nematode (Pratylenchus coffeae) infects fibrous roots of sweetpotato, and this species is one of primary sweetpotato pests in southern part of Japan. Coffee root-lesion nematodes infect the fibrous roots and make dark brownish spots on the roots. The resistance of sweetpotato cultivars and lines to coffee root-lesion nematode has been evaluated in nematodes infested fields. 'Norin No. 2', a susceptible cultivar, was cultivated in the fields to increase population density of nematodes in the previous year of field trials. The resistance of experimental cultivars and lines of sweetpotato to this nematode is determined by referring the degree of the parasitism on 'Norin No. 2' (susceptible), 'Koganesengan' (slightly susceptible) and 'Shiroyutaka' (slightly resistant). A cultivar 'Elegant 
Summer' shows low reproduction rate of this nematode (Uesugi et al. 2008).

\section{Conclusions}

This paper summarizes our current understanding of geographic distribution, symptomatology, pathogen biology, and management of the major sweetpotato pests. Pests caused by fungi, bacteria, virus, and some insects can occur at any point in the production cycle, and their prevalence is greatly influenced by the crop system and geographic location. Further research should investigate pests that occur under tropical production systems. Weevils are especially difficult to control, even with insecticides, because they feed inside the roots. Use of weevil-resistant sweetpotato cultivars appears to be a practical economical method of control. The apparent inconsistency in resistance among cultivars from season to season or location to location complicates the development of weevil-resistant sweetpotato varieties.

Further work should include in vitro screening, identifying sources of resistance in related species, and interspecific transfer, antixenosis, and antibiosis. Further international efforts should concentrate on germplasm exchange, exchange of advanced breeding lines, and advanced information management, apart from the combination of new and emerging technologies with conventional breeding techniques.

\section{Literature Cited}

Agu, C.M. (2004) Growth and yield of sweetpotato as affected by Meloidogyne incognita. Trop. Sci. 44: 89-91.

Ames, T., N.E.J.M. Smit, A.R. Braun, J.N. O'Sullivan and L.G. Skoglund (1997) Sweetpotato: Major pests, diseases, and nutritional disorders. International Potato Center, Lima, Peru.

Blank,A.F., P.A.de Silva, M.E.R. Torres and M.F.de Arrigoni-Blank (2001) Avaliação de genótipos de batata-doce quando à resistência aos insetos de solo no Estado de Sergipe. Ens. Ciê. 5: 27-34.

Bottega, D.B., C.A. Rodrigues and N. Peixoto (2010) Seleção de clones de batata-doce (Ipomoea batatas) resitenctes a Euscepes postfasciatus em condicões de campo em Ipameri, Goiás. Rev. Agr. 85: 179-184.

Cali,B.B. and J.W.Moyer (1981) Purification, serology, and particle morphology of two russet crack strains of sweet potato feathery mottle virus. Phytopathology 71: 302-305.

Carey, E.E., R.O.M. Mwanga, S. Fuentes, S. Kasule, C. Macharia, S.T. Gichuki and R.W.Gibson (1997) sweetpotato viruses in Uganda and Kenya: results of a survey. Proc. Sixth Triennial Symp. Inter. Soc. Tropical Crops-Africa Branch: 22-28.

Cervantes-Flores, J.C., G.C. Yencho, V. Pecota and B. Sosinski (2008) Detection of quantitative trait loci and inheritance of root-knot nematode resistance in sweetpotato. J. Am. Soc. Hortic. Sci. 133: 844-851.

Chung, M.L., C.H. Liao, M.J. Chen and R.J.Chiu (1985) The isolation, transmission and host range of sweet potato leaf curl disease agent in Taiwan. Plant Prot. Bull. (Taiwan) 27: 333-341.

Cipriani, G., D.Michaud, F. Brunelle, A.Golmirzaie and D.P.Zhang
(1999) Expression of soybean proteinase inhibitor in sweetpotato. In: CIP program report 1997-1998. International Potato Center, Lima, pp. 271-277.

Cipriani, G., S.Fuentes, V.Bello, L.F.Salazar, M.Ghislain and D.P. Zhang (2001) Transgene expression of rice cysteine proteinase inhibitors for the development of resistance against sweetpotato feathery mottle virus. In: CIP program report 1999-2000. International Potato Center, Lima, pp. 267-271.

Clark, C.A. and J.W.Moyer (1988a) Compendium of sweetpotato disease. The American Phytopathological Society, St. Paul: 6-9.

Clark, C.A. and J.W. Moyer (1988b) Compendium of sweetpotato disease. The American Phytopathological Society, St. Paul: 74.

C1ark, C.A. and J.W. Mayer (1988c) Compendium of sweetpotato disease. The American Phytopathological Society, St. Paul: 41-45.

Clark, C.A., P.D.Dukes and J.W.Moyer (1992) Diseases. In: Fifty years of cooperative sweetpotato research. Southern cooperative series bulletin. No. 369, pp. 88-105.

Clark, C.A., G.J.Holmes and D.M. Ferrin (2009) Chapter 7, Major Fungal and Bacterial Diseases. In: Loebenstein, G. and G. Thottappilly (eds.) The Sweetpotato, Springer, Science+Bussiness Media B.V.

Cohen, J., A. Franck, H.J.Vetten, D.E. Lesemann and G.Loebenstein (1992) Closterovirus-like particles associated with a whiteflytransmitted disease of sweetpotato. Ann. Appl. Biol. 121: 257-268.

Cohen, J., M.Milgram, Y.Antignus, M.Pearlsman, O.Lachman and G.Loebenstein (1997) Ipomoea crinkle leaf curl caused by a whitefly-transmitted Gemini-like virus. Ann. Appl. Biol. 131: 273282.

Collins, W.W., A.Jones, M.A.Mullen, N.S. Talekar and F.W.Martin (1990) Breeding sweetpotato for insect resistance: A global review. In: Jansson, R.K. and K.V. Raman (eds.) Sweetpotato management: a global perspective. Boulder and Westview Press, London, UK, pp. 379-397.

de Menezes, E.L.A. (2002) A broca da batata-doce (Euscepes postfasciatus): descrição, bionomia e controle. Circ. Técnica 6: $1-12$.

FAO (1998) FAO Production Year Book for 1996, No. 50. Food and Agriculture Organization of the United Nations, Rome, Italy: 9192.

Food and Agriculture Organization of the United Nations (FAO), Food and Agriculture Organization Statistical Databases (FAOSTAT), 2015, http: //faostat3.fao.org/browse/Q/QC/E.

França,F.H. and P.S. Ritschel (2002) Avaliação de acessos de batatadoce para resistência à broca-da-raiz, crisomelídeos e elaterídeos. Hort. Bra. 20: 79-85.

Gentile,A.G., K.A. Kimble and G.C.Hanna (1962) Reaction of sweetpotato breeding lines to Meloidogyne spp. when inoculated by an improved method. Phytopathology. 52: 1225-1226.

Giamalva, M.J., W.J.Martin and T.P.Hernandez (1963) Sweet potato varietal reaction to species and races of root-knot nematodes. Phytopathology 53: 1187-1189.

Gilbert, J.C. (1958) Some linkage studies with the $M i$ gene for resistance to root knot. Tomato Genet. Coop. Rep. 8: 15-17.

Green, S.K., C.Y.Luo and S.F. Wu (1992) Elimination of leaf curl virus of sweetpotato by meristem tip culture, heat and ribavirin. Plant Prot. Bull. (Taiwan) 34: 1-7.

Hoyer, U., W. Jelkmann, E. Maiss and H.J. Vetten (1996a) Sweetpotato sunken vein virus: another bipartite closterovirus transmitted by Bemisia tabaci Genn. In: $\mathrm{X}^{\text {th }}$ International Congress of Virology, Jerusalem, Israel, August 11-16, 1996, Abstracts W61-5, 89.

Hoyer, U., E.Maiss, W.Jelkmann, D.E.Lesemann and H.J. Vetten (1996b) Identification of the coat protein gene of a sweetpotato 
sunken vein closterovirus isolate from Kenya and evidence for a serological relationship among geographically diverse closterovirus isolates from sweetpotato. Phytopathology 86: 744-750.

Ino, M., S. Shinohara and T. Yashiki (1985) Occurrence and factors of sweet potato soil rot-like disease in Chiba prefecture. Bull. Chiba Agric. Exp. Stn. 26: 25-37.

Iuchi, M., H.Kawamura and K.Komaki (2005) Rapid and efficient methods for evaluation of resistance to Streptomyces ipomoea inoculating to small vine cuttings and storage root slices in sweetpotato. Breed. Res. 7: 45-49.

Iwahori, H., Z. Sano and T. Ogawa (2000) Distribution of main plantparasitic nematodes in sweetpotato and taro fields in Kyushu and Okinawa, Japan. 1. Survey in the central and southern parts in Kyushu Island (Kumamoto, Miyazaki and Kagoshima Prefs.) and development of an effective DNA analysis method for species identification. Kyushu Pl. Prot. Res. 46: 112-117.

Iwahori, E., R. Uesugi and W. Sugita (2015) Root-knot nematode species and the frequency of resistance-breaking nematodes in major green pepper production regions of Japan. Nematol. Res. 45: 5761.

Jansson, R.K. and K.V.Raman (1991) Sweetpotato pest management: a global overview. In: Jansson, R.K. and K.V. Raman (eds.) Sweetpotato management: a global perspective. Boulder and Westview Press, London, UK, pp. 1-12.

Jansson, R.K. (1992) Biolgocial approaches for management of weevils of root and tuber crops: a review. Fla. Entomol. 75: 568-584.

Johnson, W.A. and E.J.Cairns (1971) Effect of different nematicides on yield and quality of Centennial sweetpotato and root-knot nematode damage. J. Am. Soc. Hortic. Sci. 96: 468-471.

Kai, Y., K. Katayama, T. Sakai and M. Yoshinaga (2010) Beniharuka: a new sweetpotato cultivar for table use. Sweetpotato Res. Front 23: 2.

Karyeija, R.F., R.W. Gibson and J.P.T. Valkonen (1998) Resistance to sweet potato virus disease (SPVD) in wild East African Ipomoea. Ann. appl. Biol. 133: 39-44.

Katayama, K., T. Sakai, Y. Kai, Y. Nakazawa and M. Yoshinaga (2012) 'Konamizuki': a new sweetpotato cultivar. Bull. Natl. Agric. Res. Cent. Kyushu Okinawa Reg. 58: 15-36.

Kokkinos, C.D. and C.A. Clark (2006) Interaction among sweetpotato chlorotic stunt virus and different potyviruses and potyvirus strains infecting sweetpotato in the United States. Plant Dis. 90: 13471352.

Komiyama,A., Z.Sano, T.Murata, Y.Matusda, M. Yoshida, A. Saito and Y.Okada (2006) Resistance to two races of Meloidogyne incognita and resistance mechanism in diploid Ipomoea trifida. Breed. Sci. 56: 81-83.

Kondo, T. (1972) Varietal differences of sweet potatoes in the reproduction of Meloidogyne incognita (Kofoid et White) Chitwood. Jpn. J. Nematol. 2: 16-19.

Kudo, K. (1985) Ecology and control of a sweetpotato disease caused by Streptomyces sp. Research Journal of Food and Agriculture 8: 35-39.

Kuranouchi,T., Y.Momota, A.Takada, T.Fujita, Y.Nakamura and T.Kumagai (2012) Improvement of the field test method for screening of sweetpotato root-knot nematode (Meloidogyne incognita) resistance. Breed. Res. 14: 57-60.

Kuranouchi, T., Y.Momota, A. Takada, Y.Nakamura, T.Kumagai and M. Nakatani (2013) Effect of seedling selection on field screening for southern root-knot nematode (Meloidogyne incognita) resistance in sweetpotato. Breed. Res. 15: 32-35.

Kuranouchi,T., A.Takada, Y.Nakamura, S.Tamiya, M.Nakatani,
T. Kumagai and K. Katayama (2014) Annual variation and varietal difference in sweetpotato soil rot (Streptomyces ipomoea) resistance. Breed. Res. 16: 147-150.

Kuranouchi,T., A.Takada, Y.Nakamura, T.Fujita, M.Nakatani, T. Kumagai and K. Katayama (2015) Breeding of a new sweetpotato variety 'Hoshikogane' suitable for steamed and cured sweetpotato slices ('Hoshi-imo') with high yield and good quality. Bull. Natl. Inst. Crop Sci. 15: 1-28.

La Bonte, D.R., P.W.Wilson, A.Q. Villordon and C.A.Clark (2008) 'Evangeline' sweetpotato. HortScience 43: 258-259.

Latham, J.R. and A.K. Wilson (2008) Transcomplementation and synergism in plants: implications for viral transgenes? Mol. Plant Pathol. 9: 85-103.

Liang, Y.G., T.C. Yang and N.J.Ko (1990) Occurrence and diagnosis of geminiviruses in Taiwan. Plant Prot. Bull. (Taiwan) 32: 136-144.

Locci, R. (1994) Actinomycetes as plant pathology. Eur. J. Plant Pathol. 100: 179-200.

Loebenstein, G., G. Thottappilly, S. Fuentes and J. Cohen (2009) Chapter 8, Virus and Phytoplasma Diseases. In: Loebenstein, G. and G. Thottappilly (eds.) The Sweetpotato, Springer, Science+ Bussiness Media B.V.

Loria, R., R.A.Bukhalid, B.A.Fry and R.R.King (1997) Plant pathogenicity in the genus Streptomyces. Plant Dis. 81: 836-846.

Maingi, D., S. Sivasupramaniam, G. Brown, R. Wagner and W.R. Folk (2002) Bacillus thuringiensis and cholesterol oxidase activity against the sweetpotato weevil (Coleoptera: Curculionidae) in semi artificial diet assays. In Proceeding of the $5^{\text {th }}$ Annual meeting of the Entomological Society of America, 2002.

Mcharo, M., D.R.La Bonte, C.Clark, M.Hoy and J.H.Oard (2005) Molecular marker variability for southern root-knot nematode resistance in sweetpotato. Euphytica 144: 125-132.

Mihovilovich, E., H.A. Mendoza and L.F. Salazar (2000) Combining ability for resistance to sweetpotato feathery mottle virus. HortScience 35: 1319-1320.

Milligan, S.B., J.Bodeau, J.Yaghoobi, I.Kaloshian, P.Zabel and V.M. Williamson (1998) The root knot nematode resistance gene $\mathrm{Mi}$ from tomato is a member of the leucine zipper, nucleotide binding, leucine-rich repeat family of plant genes. Plant Cell 10: 13071319.

Moar,W.J., R.O.M. Mwanga, B. Odongo, M.Ekobu, M. Solera and M. Ghislain (2007) Progress towards engineering resistance to weevil in sweetpotato using Bt gene technology, In: Biotechnology, Breeding and Seed systems for African Crops. Maputo, Mozambique, The Rockefeller Foundation, NY, pp. 162.

Momota, Y., T. Kuraniuchi, A. Takada, T. Fujita and T. Kumagai (2012) SP-races of Meloidogyne incognita in Ibaraki and Chiba. Nematol. Res. 42: 42-43.

Mori,K., T. Takemata and Y. Ikegami (1961) Some rapid methods of estimating sweetpotato resistance to black rot. (1) Methods by stem cuttings. J. Kanto-Tosan Agri. Exp. Stn. 20: 39-52.

Mori, M., T.Usugi, T.Hayashi and M.Nishiguchi (1994) Nucleotidesequence at the 3 '-terminal region of sweetpotato feathery mottle virus (Ordinary strain, SPFMV-O) RNA. Biosci. Biotechnol. Biochem. 58: 965-967.

Moyer, J.W., C.L. Campbell, E. Echandi and W.W. Collins (1984) Improved methodology for evaluating resistance in sweetpotato to Streptomyces ipomoea. Phytopathology 74: 494-497.

Moyer, J.W., G.V.H.Jackson and E.A. Frison (eds.) (1989) FAO/ IBPGR Technical Guidelines for the Safe Movement of Sweetpotato Germplasm. Food and Agriculture Organization of the United Nations, Rome/International Board for Plant Genetic Resources, 
Rome.

Moyer, J.W. and L.F. Salazar (1989) Viruses and virus like diseases of sweetpotato. Plant Dis. 73: 451-455.

Moyer, J.W. and R.C. Larsen (1991) 18. Management of insect vectors of viruses infecting sweetpotato. In: Jansson, R.K. and K.V. Raman (eds.) Sweetpotato Pest Management, A Global perspective, Westview Press, Boulder, CO, pp. 341-358.

Muyinza, H., H.L. Talwana, R.O.M.Mwanga and P.C.Stevenson (2012) Sweetpotato weevil (Cylas spp.) resistance in African sweetpotato germplasm. Int. J. Pest Manag. 58: 73-81.

Nagata, R. (1984) Transmission of russet crack-like symptom by grafting to sweetpotato grown from apical meristem tips. Proc. Assoc. P1 Protein. Kyushu 30: 33-35.

Nakayama, H., M. Tanaka, Y. Takahata, K. Matsui, H. Iwahori, Z. Sano and M. Yoshinaga (2012) Development of AFLP-derived SCAR markers associated with resistance to two races of southern rootknot nematode in sweetpotato. Euphytica 188: 175-185.

Newell, C.A., J.M.Lowe, A. Merryweather, L.M.Rooke and W.D.O. Hamilton (1995) Transformation of sweetpotato (Ipomoea batatas (L.) Lam.) with Agrobacterium tumefaciens and regeneration of plants expressing cowpea trypsin inhibitor and snowdrop lectin. Plant Sci. 107: 215-227.

Nielsen,L.W. and J.N. Sasser (1959) Control of root-knot nematodes affecting Porto Rico sweetpotaoes. Phytopathology 49: 135-140.

Nishizawa, T. (1974) A new pathotype of Meloidogyne incognita breaking resistance of sweetpotato, and some trials to differentiate pathotype. Jpn. J. Nematol. 4: 37-42.

Ogawa, K., T. Takemata, S. Takeuchi, H.Komada and T.Ando (1979) Varietal resistance, dissemination and control of Fusarium wilt in sweetpotato. J. Cent. Agric. Exp. Stn. 30: 97-120.

Ohara-Takada,A., T.Kumagai, T.Kuranouchi, Y.Nakamura, T.Fujita, M. Nakatani, S. Tamiya and T. Katayama (2016) 'Aikomachi', a new sweetpotato cultivar with good appearance and high confectionery quality. Bull. Natl. Inst. Crop Sci. 16: 35-56.

Okada,Y., A.Saito, M. Nishiguchi, T.Kimura, M.Mori, K. Hanada, J. Sakai, C. Miyazaki, Y. Matsuda and T. Murata (2001) Virus Resistance in Transgenic Sweetpotato (Ipomoea batatas L. (Lam)) Expressing the Coat Protein Gene of Sweetpotato Feathery Mottle Virus. Theor. Appl. Genet. 103: 743-751.

Okada,Y., M.Nishiguchi, A. Saito, T.Kimura, M.Mori, K. Hanada, J. Sakai, Y. Matsuda and T. Murata (2002) Inheritance and stability of virus-resistant gene in the progeny of transgenic sweetpotato. Plant Breed. 121: 249-253.

Okada, Y. and A. Saito (2008a) Evaluation of resistance to complex infection of SPFMVs in transgenic sweetpotato. Breed Sci. 58: 243 250.

Okada, Y., H. Iwai and A. Saito (2008b) Establishing a testing method for the aphid transmission of SPFMV and evaluating viral resistance in transgenic sweetpotatoes. Breed Sci. 58: 465-468.

Okada, Y., K. Yasuda, T. Sakai and K.Ichinose (2014) Sweetpotato Resistance to Euscepes post-faciatus (Coleoptera: Curculionidae): Larval Preference Adversely Effected by Adult's Preference to Tuber for Food and Oviposition. J. Econo. Entmol. 107: 16621673.

Okada, Y., T. Sakai, M. Yoshida and K. Ichinose (2015) Protecting the sweetpotato from the West Indian sweetpotato Weevil, Euscepes Postfasciatus, II. Resistance evaluation of sweetpotato varieties to weevils in the field. Sweetpotato Res. Front 31: 2.

Osaki, T. and T. Inouye (1991) Transmission characteristics and cytopathology of a white fly-transmitted virus isolated from the sweet potato leaf curl disease. Bull. Univ. Osaka Prefecture, Ser. B,
Agric. Biol. 43: 11-19.

Overstreet,C. (2009) Chapter 9, Nematoses. In: Loebenstein, G. and G. Thottappilly (eds.) The Sweetpotato, Springer, Science+Bussiness Media B.V.

Poole, R.F. (1925) The relation of soil moisture to the pos or ground rot disease of sweetpotatoes. Phytopathology 15: 287-293.

Raman, K.V. and E.H.Alleyne (1991) Biology and management of the West Indian sweetpotato weevil, Euscepes postfasciatus. In: Jansson, R.K. and K.V.Raman (eds.) Sweetpotato management: a global perspective. Boulder and Westview Press, London, UK, pp. 263-281.

Rossel,W.H. (1981) Sweetpotato virus disease (SPVD). 74-75 in: Annu. Rep. IITA, 1980.

Sakai, J., M. Onuki, M. Mori, T. Usugi and K. Hanada (1995) Nucleotide sequence of 3'-terminal region of the genomic RNA of sweetpotato feathery mottle virus Tokushima strain. Kyusyu Agricultural Research 57: 98.

Sakai, J., S. Yamasaki, T. Ogawa, M. Ohnuki and K. Hanada (1997) Detection of sweetpotato virus G by RT-PCR from sweetpotato in Kyushu. Ann. Phytopath. Soc. Jpn. 63: 484.

Sano,Z. and H. Iwahori (2005) Regional variation in pathogenicity of Meloidogyne incognita population on sweetpotato in Kyushu Okinawa, Japan. Jpn. J. Nematol. 35: 1-12.

Sasser, J.N. and D.W. Freckman (1987) A world perspective on nematology: the role of the society. In: Veech, J.A. and D.W.Dickson (eds.) Vistas on nematology. Society of Nematologists Inc., Hyattsville, pp. 7-14.

Sherman, M. and M. Tamashiro (1954) The sweetpotato weevils in Hawaii: their biology and control. Hawaii Agric. Exp. Stn. Tech. Bull. 23: 1-36.

Shiga, T., S. Sakamoto, T.Ando, H. Ishikawa, S. Kato, T. Takemata and M. Umehara (1985) On a new sweet potato cultivar "Beniazuma". Bulletin of the National Agriculture Research Center 3: 73-84.

Silva,F.H. and P.S. Ritschel (2001) Avaliação de acessos de batatadoce para resistêntica à broca-da-raiz, crsomelídeos e elaterídeos. Horticul. Bra. 20: 79-85.

Smith, T.P., A.M.Hammond, R.N. Story and E.Burris (2013) Insect pest management in Louisiana Sweetpotatoes. LSU Ag Center No. 2620 , pp. 8 .

Sorensen, K.A. (2009) Chapter 10, Sweetpotato Insects: Identification, Biology and Management. In: Loebenstein, G. and G. Thottappilly (eds.) The Sweetpotato, Springer, Science+Bussiness Media B.V.

Suzui, T., K. Miyashita and K. Kuro (1986) First report of sweetpotato soil rot caused by Streptomyces ipomoeae. Ann. Phytopath. Soc. Japan. 52: 505.

Suzui, T. (1987) Soil rot of sweetpotato caused by Streptomyces ipomoeae. Plant Protection 41: 1-5.

Suzuki,T., T.Kobayashi, K.Adachi, H.Mochida, H.Iwahori, Y. Tateishi and K. Uesugi (2012) Effect of introducing nematoderesistant sweetpotato cultivars on crop productivity and nematode density in sweetpotato-radish double-cropping systems. Plant Prod. Sci. 15: 48-56.

Takano, Y., A.Amemiya and M. Ino (2006) Deterioration in varietal resistance to sweetpotato soil disease by virus-free treatment. Ann. Rep. Kanto-Tosan Plant Prot. Soc. 53: 29-33.

Talekar, N.S. (1988) How to control sweetpotato weevil: A practical IPM. AVRDC 88-292: 1-6.

Tateishi, Y. (2003) Increase of virulent Meloidogyne incognita populations on a resistant sweetpotato cultivar, Beniotome. Sweetpotato Res. Front 16: 4.

Tateishi, Y., Z. Sano and H. Iwahori (2007) Emergence of suppression 
of root-knot nematodes in sweetpotato cropping systems treated with Pasteuria penetrans. Jpn. J. Nematol. 37: 1-9.

Tateishi,Y., Z.Sano, H. Iwahori, K. Usugi, M.Katsura and M.Gau (2008) Suppression of root-knot nematode damage to succeeding sweetpotato by summer-sown cultivation of an oat variety, 'Tachiibuki'. Jpn. J. Nematol. 38: 1-8.

Uesugi,K., H.Iwahori and Y.Tateishi (2008) Reproduction of Pratylenchus coffeae on sweet potato cultivars. Jpn. J. Nematol. 38: $35-40$.

Ukoskit, K., P.G. Thompson and C.E. Watson, Jr. (1997) Identifying a randomly amplified polymorphic DNA (RAPD) marker linked to a gene for root-knot nematode resistance in sweetpotato. J. Am. Soc. Hortic. Sci. 122: 818-821.

Uritani, I. (2001) Sweetpotato response to insect. In: Uritani, I. (ed.) Biochemistry and molecular biology of plant stress: focusing on tropical starchy roots. Gakkai Publication Center, Tokyo, Japan, pp. 138-149.

Usugi, T., M. Nakano, A. Shinkai and T. Hayashi (1991) Three filamentous viruses isolated from sweetpotato in Japan. Ann. Phytopathol. Soc. Jpn. 57: 512-521.

Usugi, T., M.Nakano, M.Onuki, T.Maoka and T.Hayashi (1994) A new strain of sweetpotato feathery mottle virus that causes russet crack on fleshy roots of some Japanese cultivars of sweetpotato. Ann. Phytopathol. Soc. Jpn. 60: 545-554.

Wanderley, P.A., A.L. Boiça, Jr. and M.J.A. Wanderley (2004) Resistência de Cultivares de Batata-Doce a Euscepes postfasciatus Fairmaire (Coleoptera: Curculionidae). Neotrop. Entomol. 33: 371377.

Wiklund,C. (1975) The evolutionary relationship between adult oviposition preferences and larval host plant range in Papilio machaon
L. Oecologia 18: 185-197.

Wolfe, G.W. (1991) The origin and dispersal of the pest species of Cylas with a key to the pest species groups of the world. In: Jansson, R.K. and K.V.Raman (eds.) Sweetpotato management: a global perspective. Boulder and Westview Press, London, UK, pp. 13-43.

Yamasaki, S., T.Noguchi, J.Sakai, M. Onuki and K. Hanada (2000) Isolation of SPFMV strains infected in sweetpotato plants in Oita prefecture. Kyusyu Agricultural Research 62: 76.

Yamashita, M. (2003) The influence of a root-knot nematode, Meloidogyne incognita, on formation of rootsystem in sweetpotatoes (Ipomoea batatas (L), Lam)). Root Research 12: 115-118.

Yasuda,K. (1993) Seasonal prevalence of sweetpotato weevil Cylas formicarius and the West Indian sweetpotato weevil Euscepes postfaciatus in Okinawa Japan. Proc. Assoc. Plant Prot. Kyushu 39: 88-90.

Yasuda,K. (1997) Occurrence of West Indian sweetpotato weevil, Euscepes postfasciatus (Fairmaire) (Coleoptera: Curculionidae) and damage to sweetpotato (Ipomoea batatas (L.) Lam.) fields. Jpn. J. Appl. Entomol. Zool. 41: 83-88.

Yencho, G.C., K.V.Pecota, J.R. Shultheis, Z.P.VanEsbrock, G.J. Holmes, B.E.Little, A.C.Thornton and V.D.Truong (2008) 'Covington' sweetpotato. HortScience 43: 1911-1914.

Yoshida, T. (1965) On the geographical distribution of soil nematodes in Chiba prefecture. Bull. Chiba Agric. Exp. Stn. 6: 69-78.

Zhang, D., G. Cipriani, I. Rety, A. Golmirzae, N. Smit and D. Michaud (2002) Expression of protease inhibitors in sweetpotatoes. In: Michaud, D. (ed.) Recombinant Protease Inhibitors in Plants. Landes Bioscience, Georgetown, Texas, pp. 167-178. 